\title{
Kiedy marginalne staje się kluczowym. Pojęcie „(nie)przekładalność” w kontekście literatury i kultury bułgarskiej - rekonesans
}

\begin{abstract}
When Peripheral Concept Becomes a Key Issue. The Term "(Un)translatability" in the Context of Bulgarian Literature and Culture - a Reconnaissance

In recent years, in Bulgaria returns the belief of untranslatability formulated equally in relation to native literature, as well as culture and is expressed both by the creators and researchers. The term "untranslatability" appears essentially in two spaces - public discourse and scientific discourse. This article focuses on the second one, namely on scientific discourse. The paper analyzes selected articles, debates and scientific studies published in the beginning of $21^{\text {st }}$ century. The purpose of the proposed exegesis is to try to understand what Bulgarian researchers understand using the term "neprevodimost".
\end{abstract}

Keywords: translatability, Bulgarian literature, autoperception, own - foreign

Słowa kluczowe: przekładalność, literatura bułgarska, autopostrzeganie, swoje - obce

Kwestia nieprzekładalności, czy jak podkreślają encyklopedie specjalistyczne: przekładalności i jej granic, jest jednym z miejsc spornych współczesnej myśli o przekładzie, choć zajmuje w niej raczej miejsce peryferyjne. Jak słusznie zaznaczają badacze (między innymi Theo Hermans, Susan Bassnett, Edward Balcerzan), rozważania na temat (nie)przekładalności obejmują spektrum rozciągające się między dwoma punktami skrajnymi: całkowitą nieprzekładalnością (relatywizm językowy) oraz całkowitą przekładalnością (hermeneutyka). Refleksje specjalistów koncentrują się zasadniczo w na dwóch płaszczyznach: językowej i kulturowej. Problem (nie)przekładalności bywa także wykorzystywany do zilustrowania rozmaitych koncepcji i metodologii filozoficznych (między innymi przez Hansa-Georga Gadamera, Willarda Van Ormana Quine'a czy 
Jacques'a Derridę). To z natury dualistyczne pojęcie zawiera w sobie jednak także założenie o pewnej możliwości podjęcia dialogu lub jej braku. Właśnie na tym aspekcie (nie)przekładalności skupia się niniejszy tekst.

(Nie)przekładalność jest przeze mnie rozumiana z jednej strony jako sposób, tor myślenia na temat własnej kultury i jej potencjału, z drugiej zaś - na temat możliwości recepcyjnych innych kultur. Impulsem do takiego ujęcia problemu stało się powracające w ostatnich latach w Bułgarii przekonanie o nieprzekładalności, formułowane w równym stopniu w odniesieniu do rodzimej literatury, jak i do kultury, a wyrażane tak przez twórców, jak przez badaczy. Należy podkreślić, że w ostatniej dekadzie można zaobserwować swego rodzaju natężenie tego zjawiska. Warto także na wstępie zaznaczyć, iż bułgarska непреводимост definicyjnie jest właściwie tożsama ze swoim polskim odpowiednikiem ${ }^{1}$. Nie ma więc mowy o przesunięciu semantycznym jako ewentualnym źródle różnicy w użyciu terminu.

Zajmujące nas teksty ukazują się zasadniczo w dwóch przestrzeniach: dyskursu publicznego oraz dyskursu naukowego. Ten pierwszy zawiera wypowiedzi zarówno artystyczne, jak i dotyczące kultury oraz sztuki w szeroko rozumianej sferze publicznej. Za przykład może tu posłużyć artykuł zatytułowany Непреводима България (Nieprzekładalna Bułgaria), który ukazał się w 2013 roku na stronie internetowej bułgarskiego oddziału Deutche Welle ${ }^{2}$ i dotyczył fali protestów społecznych, jaka przelała się wówczas przez kraj. Dziesiątki tysięcy Bułgarów wyszły na ulice, aby zamanifestwować niezadowolenie z sytuacji w kraju, a impuls stanowiły między innymi bieda, wysokie rachunki, korupcja. Autorka artykułu zastanawia się, dlaczego w przeciwieństwie do protestów i protestujących $\mathrm{w}$ innych krajach (na przykład sąsiedniej Turcji) nie znalazły stosownego omówienia w zachodnich mediach. Emi Baruch z jednej strony stawia diagnozę, wskazując konkretne przyczyny (marginalna rola na arenie międzynarodowej, nieumiejętność komunikacji przez samych Bułgarów), z drugiej jednak podkreśla nieprzekładalność bułgarskiej polityki na ,język zachodnioeuropejski”. Użycie metonimów zachód i język zachodnioeuropejski wyznacza silną linię demarkacyjną między „my” a „oni”, traktowanymi jako jednolite zbiory. Ciekawe jest też, że głównym elementem, którego według autorki nie da się wyjaśnić nie-Bułgarom, jest zachowanie polityków, którzy mówią jedno, a robią coś przeciwnego. Bułgarska dziennikarka zdaje się odrzucać realne kategorie na rzecz symboli, a wiedzę zastępować emocjami. Baruch swój wywód podsumowuje następująco: „Jak może zostać opowiedziana $\mathrm{w}$ języku zachodnioeuropejskim historia dzisiejszej

Według Słownika Języka Polskiego PWN nieprzekładalny to taki, który nie da się przełożyć na inny język oraz nie da się wyrazić za pomocą środków właściwych innej dziedzinie. W Słowniku Języka Bułgarskiego czytamy: „непреводим - който не може да се преведе, предаде на друг език без да изгуби от точността, смисьла или художествените си качества" (taki, który nie może zostać przełożony, przekazany w języku obcym bez utraty dokładności, sensu lub wartości artystycznej).

2 https://www.dw.com/bg/\%D0\%BD\%D0\%B5\%D0\%BF\%D1\%80\%D0\%B5\%D0\%B2\%D0\% BE\%D0\%B4\%D0\%B8\%D0\%BC\%D0\%B0-\%D0\%B1\%D1\%8A\%D0\%BB\%D0\%B3\%D0\%B0\% D1\%80\%D0\%B8\%D1\%8F/a-16956904 (dostęp: 10.01.2019). 
Bułgarii, będącej (cytując Radoja Ralina) «krajem, w którym wszelka bezczelność zrobiła ogromną karierę»? Nieprzekładalne, prawda?”.

Innym przykładem jest praca artysty Kiriła Praszkowa Замяна (Шутіапа), powstała w 2012 roku. Praca miała formę instalacji w przestrzeni publicznej w formie banneru, na którym autor umieścił następującą treść: Заменям Розова за Силиконова, czyli Wymienię Różana na Silikonowa. Zestawiając nazwy dwóch dolin - najbardziej znanej bułgarskiej oraz jednej z najsławniejszych w świecie Praszkow stworzył krytyczne, wielowarstwowe dzieło, które zdaje się dość jasne w swym przekazie. A jednak i w tym przypadku pojawiają się głosy mówiące o jego nieprzekładalności. W opisie, jaki towarzyszył wystawie, czytamy: „Praca Kiriła Praszkowa [...] stanowi próbę zmiany swego rodzaju ogłoszenia prasowego w hasło-tekst. Jego sens jest nieprzetłumaczalny - wybrzmiewa tylko po bułgarsku i tylko w dzisiejszej Bułgarii”’”.

Można tu też wspomnieć o wypowiedzi pisarza Georgiego Gospodinowa tuż przed wydaniem swej powieści Физика на тъгата pod koniec 2011 roku udzielił on wywiadu, w którym nazwał bułgarski smutek nieprzetłumaczalnym. Niechaj za komentarz do niniejszego stwierdzenia posłuży fakt, że dzisiaj, siedem lat później, książka funkcjonuje w thumaczeniach na szesnaście języków.

Przykłady można by mnożyć. Artykuł ten skupia się jednak na drugim z wymienionych wyżej typów dyskursu, mianowicie na dyskursie naukowym.

Analizie poddane zostaną wybrane debaty, referaty, artykuły oraz opracowania naukowe, które dobrze funkcjonują w bułgarskiej przestrzeni naukowej oraz pośrednio w przestrzeni publicznej i kulturalnej. Celem proponowanej egzegezy jest próba zrozumienia, co bułgarscy badacze rozumieją pod terminem neprewodimost.

Chronologicznie pierwszy z omawianych tekstów, zatytułowany $O$ literaturze bułgarskiej i granicach języka4, powstał w 1998 roku i jest jednym z esejów składających się na pracę Bogdana Bogdanowa - filologa klasycznego, kulturoznawcy, współtwórcy Nowego Uniwersytetu Bułgarskiego. Tekst poświęcony jest literaturze bułgarskiej po 1989 roku. Autor poszukuje utrwalonych cech rodzimej literatury, które wpływają na jej kształt w okresie transformacji, i w tym kontekście bardzo ważne miejsce nadaje właśnie przekładalności - tego, co obce i inne. Badacz podkreśla jednak, że nie chodzi jedynie o „zewnętrzną obcość, lecz również tę mieszczącą się w granicach tego, co własne"s. Specjalista z zakresu historii literatury bułgarskiej powinien zdaniem Bogdanowa zajmować się kwestią przekładalności między różnymi typami twórczości słownej w ramach rodzimej kultury (w tym zarówno języka mówionego, jak i naukowego), aby móc stwierdzić, „,zy stosunki między nimi panujące zapewniły dynamikę konieczną do samodzielnego rozwoju, czy dynamikę rozwoju literatury zapewniało wyko-

\footnotetext{
3 Materiały promocyjne. Tekst dostępny m.in. na stronie: http://www.programata. $\mathrm{bg} / \mathrm{p}=162 \& \mathrm{c}=1 \& \mathrm{id}=75050 \& \mathrm{l}=1$ (dostęp: 20.01 .2019$)$.

4 Б. Богданов, За българската литература и пределите на езика [в:] Промяната в живота и текста, София 1998, s. 48-58. Jeśli nie podano inaczej, przekłady cytatów - M.P.

5 Ibid., s. 52.
} 
rzystanie środowiska kulturowego"'. Badanie możliwości własnej literatury powinno odbywać się zatem nie tylko poprzez analizę możliwości przyswajania obcych wzorców, lecz również poprzez „przekłady” w postaci odwołań do własnej tradycji i przeszłości. Bogdan Bogdanow zauważa, jak ważne miejsce zajmuje folklor w literaturze i kulturze bułgarskiej. Nazywa je nawet typem folklorystycznym i jako takim przypisuje obu dziedzinom zamykanie się w ramach własnych wartości. Wytwarzając stabilny obraz „własnego/swojego”, kultura bułgarska chroni tradycyjne formy i nie interesuje się „przekładem” na zewnątrz. Badacz zestawia to z twórczością słowną typu europejskiego, której otwarte istnienie skutkuje nietrwałym obrazem tego, co „swoje”, dlatego wciąż tworzy się na nowo i wymaga przekładu w różnych kierunkach. Ostatnie stwierdzenie w oczywisty sposób przywodzi na myśl założenia dwudziestowiecznej filozofii hermeneutycznej spod znaku Hansa-Georga Gadamera oraz Paula Ricoeura. Zaskakujące jest jednak postawienie kultury bułgarskiej poza granicami wzorca europejskiego. Brak gotowości na przekład, reinterpretację, nowe (inne) odczytania neguje niejako jej udział w realizacji ducha dziejów, by posłużyć się terminologią Hegla. Bogdanow pozostawia pytanie o przekładalność literatury bułgarskiej otwarte, przypominając jednocześnie ogólne rozważania na ten temat, i zgodnie ze swoją specjalnością posiłkuje się przykładami z antycznej greki.

Kwestia przekładalności bułgarskiej literatury zajmuje także Aleksandra Kiosewa, twórcę głośnej teorii o samokolonizujących się kulturach ${ }^{7}$. W wykładzie Przekładalność i nieprzektadalność literatury bułgarskiej ${ }^{8}$ badacz omawia „literaturę globalną”, którą nie tyle przeciwstawia „literaturze światowej”, ile traktuje jako swego rodzaju wynaturzenie koncepcji Goethego. Globalizacja owa nie polega jedynie na statusie literatury anglojęzycznej lub tworzonej z myśla o przekładzie na angielski, na istnieniu „produkcji literackiej” o zasięgu ponadnarodowym czy funkcjonowaniu pisarzy nomadów. „Ruchoma i transgraniczna [literatura - M.P.] posiada nie tylko własnych autorów i publiczność, lecz także instytucje: światowe festiwale, prestiżowe nagrody, globalne wydawnictwa [...], międzynarodowe domy pracy twórczej, stypendia i rezydencje"

Ibid., s. 53.

А. Кьосев, Бележки за само-колонизиращчите се култури, „Нова публичност”, Sofia 1998. Zaktualizowana wersja tekstu dostępna pod adresem: http://www.kultura.bg/media/my_html/biblioteka/bgvntgrd/b_ak.htm. W tłumaczeniu na język polski: A. Kiosew, Uwagi o samo-kolonizujących się kulturach, tłum. E. Solak, „Dekada Literacka” 2000, nr 9/10 (167/168).

8 Omawiany tekst jest wykładem plenarnym wygłoszonym w ramach międzynarodowej konferencji naukowej „Надмощие и приспособяване / Domination and adaptation”, która odbyła się w Sofii w kwietniu 2017 roku. Jak zauważa sam autor, tekst ten jest częścią większych badań naukowych (zob. A. Кьосев, Преводимост и непреводимост в съвременната българска литература [w:] Надмощие и приспособяване, Том I: Литературоведски четения в чест на 80-годишнината на професор никола георгиев, Съст. Н. Александрова, Д. Атанасова, М. Калинова, Р.Л. Станчева, Sofia 2017, s. 21-34).

9 А. Кьосев, Преводимост и непреводимост в съвременната българска литература, op. cit., s. 23. 
Punktem wyjścia rozważań Kiosewa jest przekonanie, że zjawisko to realizuje się w samym sercu języków narodowych, bułgarski zaś jest tego doskonałym przykładem.

W nim samym oraz w literaturze pisanej po bułgarsku pojawiają się dziwne rodzimo-globalne hybrydy. Jednocześnie pojawia się podobna ilość sprzeciwów wobec takiej literackiej i językowej globalizacji. Trwają procesy transformujące język bułgarski na mikropoziomach, globalizujące go od środka i zmieniające jego możliwości literaturotwórcze ${ }^{10}$.

Według badacza w wyniku owych trwających od końca XX wieku procesów język bułgarski traci swoją pamięć kulturową. Autor przywołuje poetów i poetki młodego pokolenia, którzy czerpiąc z tradycji europejskiej (często antycznej), „dekonstruują pamięć literatury narodowej”" ${ }^{11}$. Co ciekawe, według Kiosewa strategia ta tylko z pozoru przypomina twórczość bułgarskiego odrodzenia narodowego i późniejszego modernizmu. O ile od połowy XIX wieku oraz na początku wieku XX wykorzystywanie obcych wzorców stanowiło element wypełniania luki powstałej w trakcie kilkusetletniej okupacji osmańskiej i wynikającą z tego chęć dowartościowania rodzimej kultury, o tyle współcześnie, jak twierdzi badacz, ulegają one celowemu spłyceniu. Młodzi bułgarscy poeci niejako dewaluują wykorzystywane tropy i symbole. Kiosew nazywa to lirycznym autyzmem, który poprzez absurdalizację języka pozbawia go funkcji nośnika znaczeń. A zatem globalizacja ma tu na celu „całkowitą dekonstrukcję na poziomie symboliczno-ideologicznym języka bułgarskiego, w którym są pisane, pozbawienie go wszystkiego [...], co nosi znamię lokalnej aury"12. W kwestii języka Kiosew, podobnie jak Bogdan Bogdanow, zwraca uwagę w równym stopniu na język literatury, jak i na dyskurs obecny w przestrzeni publicznej. Badacz zauważa, że utrata przez bułgarszczyznę jej unikalnego charakteru jest niejako wspierana instytucjonalnie. Według niego romantyczne w swej naturze przekonanie o tym, że język narodowy i narodowa literatura są ze sobą integralnie połączone, nie jest anachronizmem ani truizmem. Więcej, nadaje mu status hipotezy naukowej, głoszącej, że:

Bułgarska tradycja literacka w swoich najwyższych i najbardziej wpływowych wzorcach nie tylko autochtonicznie wyrosła $z$ ducha języka bułgarskiego, lecz do niego powróciła i zgromadziła się w jego pamięci kulturowej w formie skojarzeń poetyckich, wyobrażeń i potencjału intertekstualnego, niesionych przez samo bułgarskie słowo historyczne. Hipoteza zakłada, że gdy bułgarscy pisarze piszą, owo nacjonalno-intertekstualne środowisko jest dla nich określającym kontekstem oraz determinującym systemem orientacyjnym: tworzą oni, jedynie kontynuując lub sprzeciwiając się, powtarzając, prowokując czy skandalizując, broniąc konserwatywnie lub atakując rewolucyjnie tę tradycję ${ }^{13}$.

W swej myśli Kiosew znowu bliski jest Bogdanowowi, kiedy podkreśla wage intertekstualności na poziomie dialogu wewnątrzkulturowego. Na tym poziomie także pojawia się nieprzekładalność. Za przykład służy badaczowi jedna z głośniejszych bułgarskich powieści ostatnich lat, Wznesienie Milena Ruskowa, której

$\begin{array}{ll}10 & \text { Ibid., s. } 25 . \\ 11 & \text { Ibid., s. } 29 . \\ 12 & \text { Ibid. } \\ 13 & \text { Ibid., s. } 24 .\end{array}$ 
autor, wykorzystując niedokończony, nieudany projekt językowy ery odrodzenia narodowego, tworzy pierwszoosobową, epicką narrację. Kiosew analizuje powieść, wskazując jej dwie podstawowe płaszczyzny, jednocześnie od razu stawia je w opozycji: przekładalna - nieprzekładalna. Do tej pierwszej należy warstwa fabularna powieści, która według badacza niesie potencjał dwoistej przekładalności. Jest z jednej strony opowieścią awanturniczo-łotrzykowską, z drugiej wpisuje się w popularną i chwytliwą poza granicami Bułgarii narrację na temat „dzikich Bałkanów”. Płaszczyzna nieprzekładalna koncentruje się wokół języka oraz mniej lub bardziej zamaskowanych odwołań kulturalno-historycznych. W tym sensie pisarstwo takie jak Ruskowa (w poezji reprezentuje je na przykład Ani Iłkow) stanowi zdaniem Kiosewa formę podwójnego sprzeciwu. Mowa tu z jednej strony o zaznaczonym już wyżej sprzeciwie wobec globalizującej się literatury, z drugiej natomiast chodzi o sprzeciw na poziomie wewnętrznym wobec zjawiska, które badacz nazywa populizmem narodowym. W tym sensie (nie)przekładalność literatury bułgarskiej w ujęciu Aleksandra Kiosewa ma charakter hermeneutyczny i przesuwa punkt ciężkości z tekstu na jego odbiorcę. Przekładalność zależna jest od kompetencji czytelników.

Zupełnie inne zastosowanie ma omawiane pojęcie w artykule Biliany Kurtaszewej Bułgarska (nie)przekładalność. O eksportowym kanonie literackim w okresie późnego socjalizmu ${ }^{14}$. Badaczka używa terminu do opisania specyfiki polityki przekładowej Bułgarii w latach siedemdziesiątych i osiemdziesiątych XX wieku. Analiza ma charakter ilościowy i prezentuje to, co z bułgarskiego „kanonu” literackiego zostało w omawianym okresie przetłumaczone na języki obce. Kanon został ujęty w cudzysłów, ponieważ okazuje się, że najczęściej tłumaczonym autorem ostatnich dekad XX wieku był Todor Żiwkow, przywódca Bułgarskiej Republiki Ludowej. Autorkę interesuje także to, w których językach tłumaczenia funkcjonowały. Zauważalne braki dotyczą języków zachodnioeuropejskich. (Nie) przekładalność odnosi się więc w tekście Kurtaszewej do mechanizmów polityki kulturalnej kraju, nie zaś do autopostrzegania. W tym kontekście dziwi użycie zajmującego nas terminu. Można by zaryzykować stwierdzenie, że „nieprzekładalność" funkcjonuje w tytule artykułu jako chwytliwe hasło, które jednocześnie nie wymaga objaśnienia, to jest jako rodzaj zwrotu utartego w języku.

Problemowi przekładalności bułgarskiej kultury został poświęcony w 2009 roku cały numer czasopisma naukowego „Literaturata” ${ }^{15}$. Uwagę zwraca konstrukcja numeru tematycznego zatytułowanego Przekładalność kultury bułgarskiej. Pierwsze pięć tekstów to rozważania teoretyczne na temat intertekstualności i kontekstualności, między innymi Umberta Eco, Jean-Louis Le Moigne'a, jak również polityk kulturowych Portugalii i Francji. Jako przekłady artykuły te nie odnoszą się w sposób bezpośredni do Bułgarii. Kolejne teksty poruszają kwestię przekładalności bułgarskiej kultury widzianej z perspektywy zewnętrznej (recepcja) oraz wewnętrznej. Tej pierwszej poświęcone jest studium Ani Burowej pod tytułem Ścieżki i przeszkody przekładalności. (Recepcja bułgarskiej

14 Б. Курташева, Българската (не)преводимост. Към литературния канон за износ на късния сочиализъм, „Култура”, брой 16 (2765), 25 април 2014.

15 „Литературата“, Год. III (2009), кн. 5. 
literatury ttumaczonej po 1989 roku ${ }^{16}$, stanowiące komentarz do znajdującej się w numerze bibliografii przekładów bułgarskiej literatury w latach 1989-2009 na niemiecki, francuski, włoski, hiszpański, węgierski, polski, czeski i słoweński. W odniesieniu do drugiego typu nieprzekładalności natomiast dwukrotnie pojawia się zapożyczony z leksyki bankowej termin конвертируемост, oznaczający konwertowalność, przeliczalność. Co według bułgarskich badaczy stanowi symboliczną „,walutę” bułgarskiej kultury? Pierwsza z analiz zatytułowana jest Конвертируемостта на съвременната българска култура, видяна от една литературна камбанария, со można przetłumaczyć jako Konwertowalność współczesnej kultury bułgarskiej, widzianej z własnego podwórka. Jej autor, znany z kontrowersyjnego stylu czy wręcz ekstrawagancji badawczej literaturoznawca i krytyk Dimityr Kamburow, stoi na stanowisku, że nie ma mniej obecnej, mniej znanej literatury w świecie niż bułgarska. Kamburow zestawia literaturę z innymi dziedzinami sztuki, które według niego są w znacznie lepszej kondycji, jak chociażby sztuki plastyczne czy muzyka poważna. Zaraz przechodzi jednak do muzyki popularnej (wyznacznikiem jest brak sukcesów na Eurowizji!), teatru oraz kina, które ocenia bardzo negatywnie. Zdaniem krytyka brak sukcesu bułgarskiej kultury polega na jej odtwórczym charakterze. Jak pisze: „Nasza kultura zawsze była znacznie lepsza na polu reprodukcji kulturalnej niźli w sferze autorskiej twórczości"17. Stąd według niego wziął się sukces chóru The Mystery of the Bulgarian Voices, który bazuje na folklorze, czy filmu Dzift ${ }^{18}$, który odtwarza kino gatunkowe - czarną komedię gangsterską.

I tu zostaje postawiona ciekawa diagnoza. Kamburow stwierdza, że bułgarski „produkt kulturowy jest nosicielem bałkańskiej i narodowej traumy niewidzialnego pęknięcia, mieszanego rodowodu: ani zachodni, ani wschodni; ani chrześcijański, ani inny; ani miejski, ani wiejski; ani wzorowy i kanoniczny, ani śmiały i wyzywający; ani cywilizowany, ani egzotyczny; ani swój, ani obcy. Wszystko to sprawia, że jest on niezauważalny, pozbawiony charakteru, fizjonomii i przynależności, jednym słowem - bury"19.

Pojawia się także znana już z uprzednio cytowanych rozpraw myśl o „folklorystycznym idiomie" bułgarskiej kultury - tu jednoznacznie negatywnie ocenianym. Autor przedstawia dość kuriozalne zestawienie wykonawców muzyki folkowej z jedną z ciekawszych i najbardziej wyjątkowych postaci bułgarskiej literatury drugiej połowy XX wieku, Jordanem Radiczkowem. Na koniec krytyk proponuje porównanie literatury do piłki nożnej. Analizuje więc okres, kiedy Bułgaria święciła tryumfy w tym sporcie, i zauważa wyróżniający, charakterystyczny styl drużyny, którego brakuje teraz według Kamburowa tak bułgarskiemu futbolowi, jak literaturze.

16 А. Бурова, Пътища и прегради на преводимостта. (Преводната рецепщия на българската литература след 1989 г.), „Литературата”, ор. cit., s. 106-117.

17 Д. Камбуров, Конвертируемостта на съвременната българска култура, видяна от една литературна камбанария, „Литературата”, ор. cit., s. 87.

18 Film Jawora Gyrdewa w polskiej dystrybucji zatytułowany Śmieć.

19 Д. Камбуров, Конвертируемостта на съвременната българска култура ..., op. cit., s. 87. 
Drugi z tekstów, w którym wykorzystany zostaje termin „konwertowalność”, to szkic Ełki Nikołowej, którego tytuł - Konwertowalność literatury bułgarskiej?20 zdaje się zapowiadać polemikę z Dimitrem Kamburowem. Tymczasem czytelnik dostaje niezbyt pogłębione przemyślenia na temat szans literatury bułgarskiej w zglobalizowanym świecie, w którym, jak podkreśla autorka, badacze wskazują na dwie możliwości, podsumowane przez Nikołową anglojęzycznymi frazami: Nothing is translatable oraz Everything is translatable. Następnie Nikołowa przechodzi do zdawkowego omówienia sytuacji literatury bułgarskiej w Holandii, zahaczając o politykę kulturalną (przekładową) swojego kraju. Ani jeden, ani drugi tekst nie objaśniają, czym miałaby być konwertowalność kultury i jak pojęcie to odnosi się do przekładalności.

Z wewnętrznej perspektywy analizują przekładalność bułgarskiej literatury jeszcze dwa teksty w omawianym numerze pisma „Literaturata”: Niewidzialna granica tego, co butgarskie: modelowanie czytelnika w najnowszej beletrystyce butgarskiej Bojki Penczewa ${ }^{21}$ oraz $W$ centrum peryferii albo Nasza Złota Klatka Bojana Wyłczewa ${ }^{22}$. Penczew rozpoczyna od stwierdzenia, że bułgarska proza jest coraz bardziej sprofesjonalizowana, stara się dotrzeć do jak najszerszej grupy odbiorców poprzez zamierzone otwarcie na inne potencjalne media (głównie kino) oraz języki. Badacz sprawdza, czy powszechnie wyrażane przez bułgarskich autorów przekonanie, jakoby pisali „dla każdego”, jest prawdziwe. Tym samym Penczewa, podobnie jak Kiosewa, zajmują de facto implikowane kompetencje rodzimego czytelnika. Artykuł Wyłczewa z kolei stanowi obszerną relację z pracy wykładowcy literatury bułgarskiej na Uniwersytecie Kolońskim. Autor opisuje swój autorski kurs prezentujący wybór najważniejszych dzieł drugiej połowy XX wieku, dopełniony przez trzy filmy fabularne. Jak się okazuje, kryterium doboru była dostępność tekstów kultury w przekładzie na język niemiecki. Artykuł ma charakter sprawozdawczy, a najbardziej interesująca dla jego autora okazuje się recepcja poszczególnych utworów przez niemieckich studentów. Tym bardziej zaskakujące okazuje się podsumowanie tekstu, które warto przytoczyć w całości.

Z wieloletniej praktyki zawodowej wykładowcy i tłumacza wiem jednak, że pełna treści wielopoziomowość naszej mowy, cała jej elastyczność i głęboka uczuciowość, całe jej bogactwo w niuanse i kontrasty, nieskończona synonimika, szczególnie w obszarze emocjonalnym, pozostają niedocenione i nieprzyswajalne przez obcokrajowców. Nawet jeśli wszystkie pozostałe elementy zostały przyswojone, obcokrajowcy nigdy nie dochodzą do prawdziwej głębokiej istoty naszego języka, do jego ukrytego ducha. Tak aby czytając Botewa, Jaworowa, Debelanowa, Jowkowa, wszystkimi zmysłami wyłapać obraz świata, bułgarski obraz świata, bułgarski obraz bułgarskiego świata w jego pełnej krasie.

O tym przekonał mnie ten kurs: jesteśmy zamknięci i pozostaniemy zamknięci w naszej złotej klatce - naszej historii, naszej literaturze i naszym języku. Klatce, której wartość

20 Е. Николова, Конвертируемост на българската литература?, „Литературата”, op. cit., s. $201-208$

21 Б. Пенчев, Невидимата гранииа на българското: моделирането на читателя в найновата българска белетристика, „Литературата”, op. cit., s. 152-163.

22 Б. Вълчев, В иентъра на периферията или Нашият златен кафез, „Литературата”, op. cit., s. 175-200. 
jesteśmy w stanie docenić tylko my i której możliwości tylko my jesteśmy w stanie w pełni i wszechstronnie wykorzystać. Klatce, w której tylko my możemy poczuć się prawdziwie wolni. Złotej, lecz klatce... Klatce, lecz ze złota... ${ }^{23}$

Obok powyższych w omawianym numerze czasopisma znajdują się także dwa teksty poświęcone teatrowi oraz kinu bułgarskiemu w kontekście rozpoznawalności na tle europejskim ${ }^{24}$.

Ostatni przykład, który pragnę tu przywołać, ma charakter popularyzujący naukę. Jest to dyskusja, która odbyła się w 2012 roku w ramach cyklu spotkań „Kultura w dobie kryzysu" i która nosi taki sam tytuł jak omawiany powyżej numer tematyczny czasopisma „Literaturata”, czyli Przekładalność kultury bułgarskiej25. W rozmowie udział wzięli specjaliści z zakresu literatury (w tym tłumaczki: Iglika Wasiliewa, Angela Rodel, oraz literaturoznawczyni Ani Burowa), kina (Nadeżda Marinczewska) i teatru (Asen Terziew). Sama debata nie dotyczyła jednak zagadnienia przekładalności. Po raz kolejny zostało ono użyte w formie chwytu przykuwającego uwagę lub, co bardziej prawdopodobne, tak jak w przypadku tekstu Biliany Kurtaszewej, słowa klucza uogólniającego sposoby funkcjonowania literatury i kultury bułgarskiej poza granicami kraju oraz polityki kulturowej Bułgarii, w tym polityki przekładowej.

Jak zostało zaznaczone w tytule, niniejszy tekst stanowi swego rodzaju rekonesans na temat frekwencji oraz sposobów funkcjonowania pojęcia (nie)przekładalności w bułgarskim dyskursie i obejmuje jedynie wycinek badanego zagadnienia. Jednak już na podstawie zaprezentowanego materiału można sformułować pierwsze wnioski. (Nie)przekładalność w bułgarskim dyskursie publicznym oraz naukowym pojawia się zasadniczo w trzech znaczeniach. Pierwsze z nich odnosi się do polityki kulturalnej (głównie przekładowej), mechanizmów rządzących tym, co z bułgarskiej literatury i kultury pojawia się poza granicami kraju. (Nie) przekładalność jest więc w tym kontekście pojęciem, za którym kryje się krytyka systemu. Drugie można nazwać znaczeniem słownikowym, gdyż z mniejszą lub większą emfazą wyraża przekonanie o niemożności wytłumaczenia tego, co bułgarskie, nosicielom innych języków i kultur. Tu warto zwrócić uwagę na natężenie występowania omawianego pojęcia w dyskursie publicznym. I wreszcie znaczenie trzecie, a w moim przekonaniu najciekawsze, które pozornie przenosi pojęcie (nie)przekładalności na płaszczyznę intra, a tak naprawdę wskazuje na wyjątkowy charakter kultury bułgarskiej. Tym samym wpisuje się w stworzony w okresie odrodzenia narodowego model kultury oparty na opozycji „swoje obce".

23 Ibid., s. 200.

24 Zob. П. Александрова, Българското кино в опит да се измъкне от маргиналността, „Литературата”, op. cit., s. 209-221, oraz К. Николова, Българският театър в европейска перспектива, „Литературата”, ор. cit., s. 222-229.

25 Zapis debaty został opublikowany w dodatku specjalnym do czasopisma „Literaturen westnik” (zob. „Литературен вестник”, 25.04-1.05.2012, г. 21, бр. 15). 


\section{Bibliografia}

Александрова П., Българското кино в опит да се измъкне от маргиналността, „Литературата”, Год. III (2009), кн. 5, s. 209-221.

Богданов Б., За българската литература и пределите на езика [в:] Промяната в живота и текста, София 1998, s. 48-58.

Бурова А., Пътищза и прегради на преводимостта. (Преводната рецеепичи на българската литература след 1989 г.), „Литературата”, Год. III (2009), кн. 5, s. 106-117.

Вълчев Б., В иеентъра на периферията или Нашият златен кафез, „Литературата", Год. III (2009), кн. 5, s. 175-200.

Камбуров Д., Конвертируемостта на съвременната българска култура, видяна от една литературна камбанария, „Литературата”, Год. III (2009), кн. 5, s. $83-105$.

Курташева Б., Българската (не)преводимост. Към литературния канон за износ на късния сочиализъм, „Култура”, брой 16 (2765), 25 април 2014.

Кьосев А., Бележки за само-колонизиращите се култури, „Нова публичност”, Sofia 1998.

Кьосев А., Преводимост и непреводимост в съвременната българска литература [w:] Надмощие и приспособяване, Том I: Литературоведски четения в чест на 80-годишнината на професор Никола Георгиев, съст. Н. Александрова, Д. Атанасова, М. Калинова, Р.Л. Станчева, Sofia 2017, s. $21-34$.

„Литературен вестник”, 25.04-1.05.2012, г. 21, бр. 15.

Николова К., Българският театър в европейска перспектива, „Литературата”, Год. III (2009), кн. 5, s. 222-229.

Николова Е., Конвертируемост на българската литература, „Литературата”, Год. III (2009), кн. 5, s. 201-208.

Пенчев Б., Невидимата граница на българското: моделирането на читателя 6 най-новата българска белетристика, „Литературата”, Год. III (2009), кн. 5, s. $152-163$. 